\title{
Evaluation of genetic similarity between accessions of Pityrocarpa moniliformis (angico-de-bezerro) using RAPD markers
}

\author{
F.M.S. Sousa ${ }^{1}$, R.M. Mendes ${ }^{1}$, R.F.M. Mendes ${ }^{2}$, R.B. Araujo Neto ${ }^{3}$, \\ M.P.S.B.C. Nascimento ${ }^{3}$ and P.S.C. Lima ${ }^{3}$ \\ ${ }^{1}$ Universidade Estadual do Piauí, Campus Universitário Torquato Neto, \\ Teresina, PI, Brasil \\ ${ }^{2}$ Universidade Federal do Piauí, Campus Universitário Ministro Petrônio Portella, \\ Teresina, PI, Brasil \\ ${ }^{3}$ Embrapa Meio-Norte, Teresina, PI, Brasil \\ Corresponding author: P.S.C. Lima \\ E-mail: paulo.costa-lima@embrapa.br
}

Genet. Mol. Res. 13 (3): 5815-5821 (2014)

Received November 11, 2013

Accepted May 28, 2014

Published July 29, 2014

DOI http://dx.doi.org/10.4238/2014.July.29.9

\begin{abstract}
Pityrocarpa moniliformis (Benth.) Luckow and Jobson, commonly known as angico-de-bezerro, is a forage legume that occurs naturally in the Caatinga of northeastern Brazil. This fast growing, vigorous, melliferous tree is well adapted to arid terrains and its branches and leaves possess high nutritional value. However, the scarcity of information regarding genetic variability within the species limits its possible exploitation as an animal forage. The aim of the study was to evaluate the genetic similarities of ten accessions of $P$. moniliformis available in the active germplasm collection of Embrapa Meio-Norte, using the RAPD markers to select those most suitable for cultivation and/or plant breeding. Polymerase chain reaction using ten selected RAPD primers generated 110 amplified loci, 106 (96.4\%) of which were polymorphic. Primers A10 and M06 produced the largest number of polymorphic loci (18 and 13 bands, respectively),
\end{abstract}


while primers B18 and K15 generated the smallest number ( 7 bands each). The dendrogram, constructed using the Jaccard coefficients and considering a cut-off point of 0.41 allowed the separation of the ten accessions into four genotypic groups. The highest genetic similarity coefficient (0.56) was observed between group I accessions BGFAB6 and BGFAB9 and BGFAB 7 and BGFAB 8, while the lowest coefficient (0.11) was observed between accessions BGFAB3 (group IV) and BGFAB10 (group III). The results revealed that genetic variability is present in the accessions of $P$. moniliformis.

Key words: Forage legume; DNA markers; Genetic variability

\section{INTRODUCTION}

Leguminous forage crops exhibit productivities and nutritional qualities that are generally superior to those of grasses and maintain their nutritional characteristics for longer periods (Pereira et al., 2001). A survey of the uses of local native plants in three places in the Brazilian State of Piauí (Nascimento et al., 2007) revealed that Pityrocarpa moniliformis (Benth.) Luckow and Jobson (Fabaceae: Mimosoideae) was one of the species most commonly used by farmers as a source of animal feed. This fast-growing, vigorous, melliferous plant is well adapted to arid terrains and is frequently found in the Caatinga of northeastern Brazil, especially in the states of Maranhão, Piauí, Ceará, and Bahia, where it is known as angicode-bezerro. It is an arboreal species ranging from 4 to $9 \mathrm{~m}$, and the slender branches contain relatively high levels of protein $(19.14 \%), \mathrm{P}(0.16 \%)$ and $\mathrm{Ca}(0.10 \%)$. The branches and leaves of $P$. moniliformis remain green even during the dry season, thus providing an important source of fodder for cattle and goats in the Caatinga (Lorenzi, 2002). However, exploitation of this plant species as a forage crop is limited due to the lack of knowledge of the relevant characteristics and genetic variability within the species, information that is essential for the success of conservation and breeding programs.

Molecular markers have been extensively used in plant breeding programs, since they provide an unlimited number of DNA polymorphisms that are independent of environmental effects and of the physiological status of the plants, thereby allowing the early identification of individuals with desirable traits (Lanza et al., 2000). Among the molecular techniques based on the polymerase chain reaction (PCR), the method employing random amplified polymorphic DNA (RAPD) markers appears to be most advantageous because it is highly sensitive and can detect polymorphisms very fast without prior knowledge of genomic DNA sequences. Furthermore, the RAPD technique is low cost and can be readily implemented in the nonspecialized laboratory (Bueno et al., 2001).

RAPD markers have been used in studies with forage legumes due to attributes with respect to cost, ease of use and polymorphism. Ulloa et al. (2003) used RAPD markers to evaluate the genetic diversity in populations of Trifolium pretense, and Bortolini et al. (2006) analyzed the genetic variability of 78 accessions of Trifolium repens with 24 RAPD primers, while Malviya and Yadav (2010) evaluated the diversity of 17 cultivars of Cajanus cajan using 17 RAPD primers. 
The active germplasm bank of native forage species maintained by Embrapa MeioNorte contains various accessions of $P$. moniliformis that need to be fully characterized. The aim of the present study was to evaluate the genetic similarity of ten accessions of angico-debezerro using the RAPD technique.

\section{MATERIAL AND METHODS}

\section{Plant material}

Ten accessions of angico-de-bezerro from the active germplasm collection of Embrapa Meio-Norte originating from the counties of Teresina (BGFAB3 and BGFAB7) and São João (BGFAB1, BGFAB2, BGFAB4, BGFAB5, BGFAB6, BGFAB8, BGFAB9, BGFAB10) in the State of Piauí, Brazil, were evaluated.

\section{DNA extraction}

Young healthy leaves were collected from each accession and immediately subjected to DNA extraction with the aid of DNeasy Plant Mini kits (Qiagen, Valencia, CA, USA), employed according to the recommendations of the manufacturer (Qiagen, 2006). Samples of leaves $(100 \mathrm{mg})$ were separately macerated in 2-mL tubes, containing five 3-mm glass beads and buffers from the extraction kit, with the aid of a Precellys ${ }^{\circledR} 24$ tissue homogenizer/grinder (Bertin, Montigny-le-Bretonneux, France). Aliquots of DNA extracted were subjected to electrophoresis on a $0.8 \%$ agarose gel in Tris-borate-EDTA (0.5X TBE) buffer and stained with SYBR $^{\circledR}$ Safe DNA Gel Stain (10,000X; Invitrogen, Carlsbad, CA, USA). Genomic DNA was quantified by comparison with $\lambda$ DNA standards (150 ng), and the quality estimated by spectrophotometric analysis of $2-\mu \mathrm{L}$ aliquots using a NanoDrop (Wilmington, DE, USA) model 2000 spectrophotometer. DNA samples were diluted in Tris-EDTA (TE) buffer to a final concentration of $15 \mathrm{ng} / \mu \mathrm{L}$ and stored at $-20^{\circ} \mathrm{C}$ until required for RAPD reactions.

\section{DNA amplification}

PCR amplifications were carried out in 0.2-mL microtubes using a Veriti 96-well thermal cycler (Applied Biosystems, Foster City, CA, USA) using a reaction mixture comprising 1.2X Invitrogen buffer (20 mM Tris-HCl, $0.1 \mathrm{mM}$ EDTA, $1 \mathrm{mM} \mathrm{DTT,} \mathrm{50 \%} \mathrm{(v/v)} \mathrm{glycerol;} \mathrm{pH}$ 8.0), $3.0 \mathrm{mM} \mathrm{MgCl}$ (Invitrogen), $0.75 \mathrm{mM}$ dNTPs (Invitrogen), $1 \mathrm{U}$ Taq DNA polymerase (Sigma, St. Louis, MO, USA), $0.2 \mu \mathrm{M}$ primer, $1 \mu \mathrm{L}$ DNA template $(\sim 15 \mathrm{ng})$, and ultrapure distilled water to a final volume of $20 \mu \mathrm{L}$. The PCR conditions were: initial denaturation at $92^{\circ} \mathrm{C}$ for $1 \mathrm{~min}, 45$ cycles comprising denaturation at $92^{\circ} \mathrm{C}$ for $40 \mathrm{~s}$, annealing at $34^{\circ} \mathrm{C}$ for 1 min and extension at $72^{\circ} \mathrm{C}$ for $2 \mathrm{~min}$, and final extension at $72^{\circ} \mathrm{C}$ for $5 \mathrm{~min}$.

Genomic DNA samples were amplified using 68 primers obtained from Operon Technologies (Alameda, CA, USA) to select the primers for RAPD reactions. Ten primers (Table 1) were chosen on the basis of resolution and high levels of polymorphism, and these were subsequently employed in the amplification of DNA samples from each of the ten P. moniliformis accessions. The resulting amplicons were separated by electrophoresis on a $1.5 \%$ agarose gel in $0.5 \mathrm{X}$ TBE at $110 \mathrm{~V}$ for approximately $3 \mathrm{~h}$, stained with GelRed ${ }^{\mathrm{TM}}$ (Biotium, Hayward, CA, 
USA), visualized under a UV transilluminator and photographed. Invitrogen 50-bp and 1-kb DNA ladders were used as molecular weight markers.

\begin{tabular}{|c|c|c|c|c|}
\hline \multirow[t]{2}{*}{ Primer } & \multirow[t]{2}{*}{ Nucleotide sequence } & \multicolumn{2}{|c|}{ No. of fragments } & \multirow[t]{2}{*}{$\%$ Polymorphism } \\
\hline & & Amplified & Polymorphic & \\
\hline A07 & 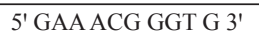 & 11 & 11 & 100 \\
\hline A10 & $5^{\prime}$ GTG ATC GCA G $3^{\prime}$ & 18 & 18 & 100 \\
\hline B04 & $5^{\prime}$ GGA CTG GAG T $3^{\prime}$ & 12 & 11 & 91.6 \\
\hline B10 & $5^{\prime}$ CTG CTG GGA C $3^{\prime}$ & 8 & 8 & 100 \\
\hline B18 & $5^{\prime} \mathrm{CCA}$ CAG CAG T $3^{\prime}$ & 7 & 7 & 100 \\
\hline K15 & $5^{\prime}$ CTC CTG CCA A $3^{\prime}$ & 10 & 7 & 70 \\
\hline M05 & 5' GGG AAC GTG T 3' & 12 & 12 & 100 \\
\hline M06 & 5' CTG GGC AAC T 3' & 13 & 13 & 100 \\
\hline M11 & 5' GTC CAC TGT G 3' & 10 & 10 & 100 \\
\hline N06 & 5' GAG ACG CAC A $3^{\prime}$ & 9 & 9 & 100 \\
\hline Total & & 110 & 106 & 96 \\
\hline
\end{tabular}

\section{Statistical analysis}

The number of polymorphic bands generated by each primer was determined by visual inspection, taking into account only those bands showing medium or strong intensities. Each band was considered to represent a single character, and a binary matrix was created, in which 1 indicated the presence of the band and 0 its absence. Genetic similarities between accessions of $P$. moniliformis were estimated from Jaccard coefficients and the corresponding similarity matrix. A dendrogram was constructed using the unweighted pair group method with arithmetic average (UPGMA) clustering technique. The cophenetic correlation coefficient $(r)$ was calculated from the similarity matrix and the dendrogram. The bootstrap confidence index was also evaluated from the binary matrix of amplified fragments generating a dendrogram from 1000 permutations. The cut-off point was based on the mean genetic similarity $\left(s g_{\mathrm{m}}\right)$ calculated according to the equation: $s g_{\mathrm{m}}=\Sigma s g_{\mathrm{ij}} / N$, in which $s g_{i j}$ is the genetic similarity between pairs of individuals and $N$ is the number of pairs obtained from 1000 permutations. Analyses were performed with the aid of the PAST version 1.34 software (Hammer et al., 2001).

\section{RESULTS AND DISCUSSION}

The ten primers selected for the RAPD analysis of the accessions of P. moniliformis produced 110 fragments ranging in size from 375 to $3054 \mathrm{bp}$ (Table 1), values that were similar to those obtained in the RAPD analysis of white clover (T. repens; Bortolini et al., 2006) and hyacinth bean (Lablab purpureus; Rai et al., 2010). The proportion of amplified loci that were polymorphic $(96.4 \% ; 106 / 110)$ was substantially higher than values previously reported for the forage legumes Pueraria montana var. lobata (55.3\%; Heider et al., 2007) and C. cajan (74.7\%; Malviya and Yadav, 2010) in RAPD reactions involving 12 and 17 primers, respectively, but slightly lower than that obtained for Arachis pintoi (98\%) in RAPD reactions with 18 primers (Carvalho et al., 2010). The high level of polymorphic loci observed in P. moniliformis with a small number of primers complies with the view that non-domesticated species normally exhibit greater polymorphism than do domesticated species (Innan and Kim, 2004). 
Primers A10 and M06 (Figure 1) generated the largest numbers of polymorphic loci (18 and 13 bands, respectively) while primers B18 and K15 produced the smallest numbers (7 bands each). The average number of polymorphic bands produced per primer was 10.6, a value similar to that reported for 69 accessions of Flemingia macrophylla (11 bands per primer; Andersson et al., 2006) and greater than that reported for 30 cultivars of L. purpureus (5.7 bands per primer; Rai et al., 2010).

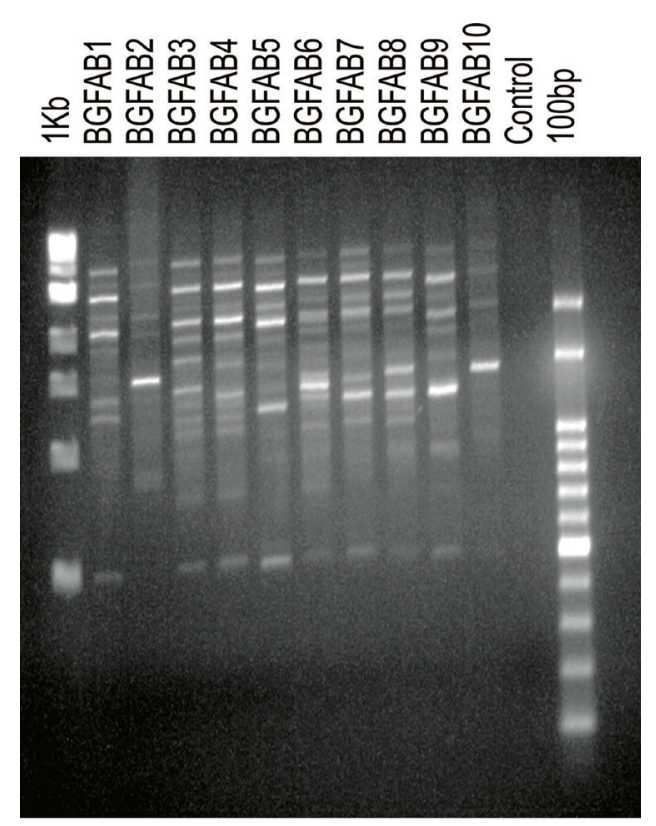

Figure 1. Electrophoretic profiles of RAPD amplifications of DNA samples from ten accessions of Pityrocarpa moniliformis (angico-de-bezerro) generated by primer M06.

The coefficients of genetic similarity between accessions of $P$. moniliformis ranged from 0.11 to 0.56 (Table 2). This variation was greater than that observed with domesticated and autogamous forage legumes such as Stylosanthes macrocephala (Barros et al., 2005) and Vigna radiata (Lakhanpaul et al., 2000).

Table 2. Genetic similarity matrix for ten accessions of Pityrocarpa moniliformis (angico-de-bezerro) generated from Jaccard's coefficients calculated on the basis of RAPD markers.

\begin{tabular}{|c|c|c|c|c|c|c|c|c|c|c|}
\hline & BGFAB1 & BGFAB2 & BGFAB3 & BGFAB4 & BGFAB5 & BGFAB6 & BGFAB7 & BGFAB8 & BGFAB9 & BGFAB 10 \\
\hline BGFAB1 & 1 & & & & & & & & & \\
\hline BGFAB2 & 0.46 & 1 & & & & & & & & \\
\hline BGFAB3 & 0.28 & 0.37 & 1 & & & & & & & \\
\hline BGFAB4 & 0.55 & 0.52 & 0.41 & 1 & & & & & & \\
\hline BGFAB5 & 0.39 & 0.43 & 0.30 & 0.37 & 1 & & & & & \\
\hline BGFAB6 & 0.43 & 0.45 & 0.36 & 0.50 & 0.43 & 1 & & & & \\
\hline BGFAB7 & 0.42 & 0.42 & 0.38 & 0.50 & 0.39 & 0.49 & 1 & & & \\
\hline BGFAB8 & 0.40 & 0.42 & 0.31 & 0.47 & 0.38 & 0.52 & 0.56 & 1 & & \\
\hline BGFAB9 & 0.51 & 0.42 & 0.32 & 0.47 & 0.42 & 0.56 & 0.43 & 0.44 & 1 & \\
\hline BGFAB 10 & 0.38 & 0.40 & 0.11 & 0.28 & 0.31 & 0.38 & 0.33 & 0.39 & 0.45 & 1 \\
\hline
\end{tabular}


The large variation in genetic similarity coefficients observed in P. moniliformis was probably due to the non-domesticated nature of the species, since such conditions favor heterogeneity (Vieira et al., 2003). Furthermore, members of the genus Pityrocarpa are exclusively allogamous, a characteristic that contributes to increased genetic variability in comparison with autogamous plants (Ferreira, 2009).

The cophenetic correlation of $80 \%$ demonstrated the good agreement between the Jaccard similarity matrix and the dendrogram constructed using the UPGMA method. Delimitation of the dendrogram with a cut-off point of 0.41 revealed the genetic interrelationships between the ten $P$. moniliformis accessions and allowed the separation of the accessions into four genotypic groups (Figure 2). Group I included the accessions BGFAB1, BGFAB2, BGFAB4, BGFAB6, BGFAB9, and BGFAB7, collected in São João, PI, and accession BGFAB8, collected in Teresina, PI, suggesting that the last did not originate from the area in which it was collected. Groups II, III and IV comprised one accession each (BGFAB5, BGFAB10 and BGFAB3, respectively), indicating that the diversity of the species could be better exploited if more accessions were collected, confirming the conclusion of Barros et al. (2005) based on the identification of groups of $S$. macrocephala containing few accessions.

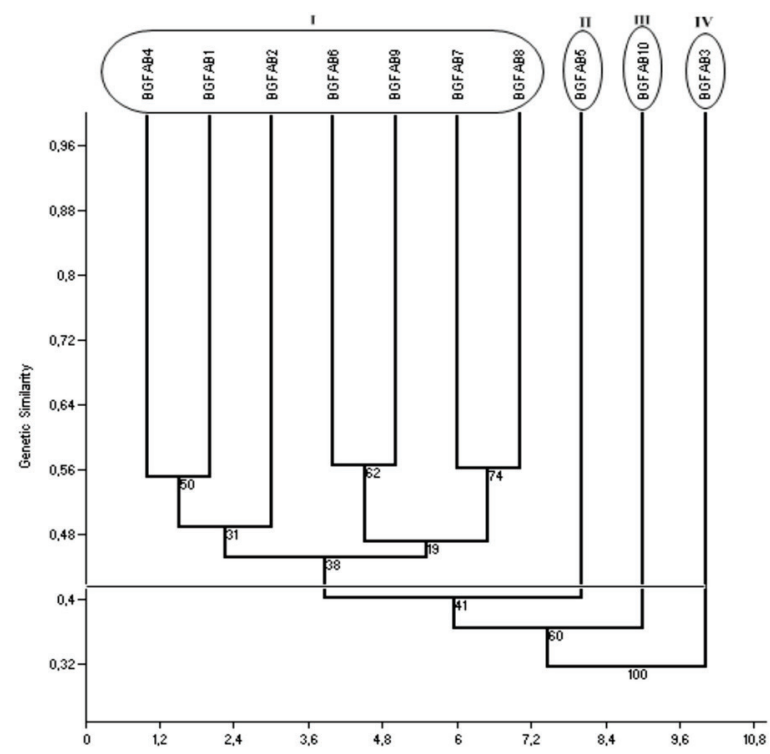

Figure 2. UPGMA dendrogram based on ten RAPD polymorphic markers showing similarity relationships between ten accessions of Pityrocarpa moniliformis (angico-de-bezerro).

When individual accessions were pairwise compared, the highest genetic similarity coefficients were observed between group I accessions BGFAB7 from Teresina and BGFAB8 from São João and accessions BGFAB6 and BGFAB9 from São João, while the lowest coefficient was observed between accessions BGFAB10 (group III) and BGFAB3 (group IV). The results presented herein revealed that genetic variability is present in the accessions of $P$. moniliformis available in the active germplasm collection of Embrapa Meio-Norte, which can be exploited in future breeding programs. 


\title{
ACKNOWLEDGMENTS
}

\author{
Research supported by Embrapa-Macroprograma 1.
}

\section{REFERENCES}

Andersson MS, Peters M, Schultze-Kraft R, Gallego G, et al. (2006). Molecular characterization of a collection of the tropical multipurpose shrub legume Flemingia macrophylla. Agroforest. Syst. 68: 231-245.

Barros AM, Faleiro FG, Karia CT and Shiratsuchi LS (2005). Variabilidade genética e ecológica de Stylosanthes macrocephala determinadas por RAPD e SIG. Pesq. Agr. Bras. 40: 899-909.

Bortolini F, Dall'agnol M and Schifino-wittmann MT (2006). Molecular characterization of the USDA white clover (Trifolium repens L.) core collection by RAPD markers. Gen. Res. Crop Evol. 53: 1081-1087.

Bueno LCS, Mendes ANG and Carvalho SP (2001). Melhoramento de Plantas: Princípios e Procedimentos. UFLA, Lavras.

Carvalho MA, Quesenberry KH and Gallo M (2010). Comparative assessment of variation in the USA Arachis pintoi (Krap. and Greg.) germplasm collection using RAPD profiling and tissue culture regeneration ability. Plant Syst. Evol. 288: 245-251.

Ferreira MHS (2009). Polinização e mirmecolia em Pityrocarpa moniliformis (Leg.: Mimosoideae). Master's Thesis. Programa de Pós-graduação em Botânica, Feira de Santana.

Hammer O, Harper DAT and Ryan PD (2001). PAST: Paleontological statistics software package for education and data analysis. Paleontol. Electron. 4: 1-9.

Heider B, Fischer E, Berndl T and Schultze-Kraft R (2007). Analysis of genetic variation among accessions of Pueraria montana (Lour.) Merr. var. lobata and Pueraria phaseoloides (Roxb.) Benth. based on RAPD markers. Gen. Res. Crop. Evol. 54: 529-542.

Innan H and Kim Y (2004). Pattern of polymorphism after strong artificial selection in a domestication event. Proc. Natl. Acad. Sci. U. S. A. 101: 10667-10672.

Lakhanpaul S, Chadha S and Bhat KV (2000). Random amplified polymorphic DNA (RAPD) analysis in Indian mung bean (Vigna radiata (L.) Wilczek) cultivars. Genetica 109: 227-234.

Lanza MA, Schuster I and Guimarães CT (2000). Aplicação de marcadores moleculares no melhoramento genético. Informe Agrop. 21: 97-108.

Lorenzi H (2002). Árvores Brasileiras: Manual de Identificação e Cultivo de Plantas Arbóreas Nativas do Brasil. Plantarum, Nova Odessa.

Malviya N and Yadav D (2010). RAPD analysis among pigeon pea [Cajanus cajan (L.) Mill sp.] cultivars for their genetic diversity. Genet. Eng. Biotechnol. J. GEBJ-1.

Nascimento MPSCB, Oliveira ME and Nascimento HTS (2007). Descrição e Usos de Plantas Nativas no Assentamento Marrecas. In: Plantas do Semi-Árido: Conhecimento e Usos no Assentamento Marrecas (Nascimento MPSCB, ed.). Embrapa Meio-Norte, Teresina, 33-157.

Pereira AV, Valle CB, Ferreira RP and Miles JW (2001). Melhoramento de Forrageiras Tropicais. In: 601 (Nass LL, Valois ACC, Melo IS and Inglis MCV, eds.). Recursos Genéticos e Melhoramento de Plantas, Rondonópolis.

Qiagen (2006). DNeasy Plant Handbook, July 2006, Valencia. Available at [http://www.qiagen.com/Products/Catalog/ Sample-Technologies/DNA-Sample-Technologies/Genomic-DNA/DNeasy-96-Plant-Kit\#orderinginformation]. Accessed: March 20, 2013.

Rai N, Kumar A, Singh PK and Singh M (2010). Genetic relationship among hyacinth bean (Lablab purpureus) genotypes cultivars from different races based on quantitative traits and random amplified polymorphic DNA marker (Art). African J. Biotechnol. 9: 137-144.

Ulloa O, Ortega F and Campos H (2003). Analysis of genetic diversity in red clover (Trifolium pratense L.) breeding populations as revealed by RAPD genetic markers. Genome 46: 529-535.

Vieira RF, Goldsbrough P and Simon JE (2003). Genetic diversity of basil (Ocimum spp.) based on RAPD markers. $J$. Am. Soc. Hort. Sci. 128: 94-99. 